\title{
FOOD AND BEVERAGE MODERNITY IN THE SEGMENT OF CAPSULE MACHINES: A STUDY BASED ON THE MEANS-END THEORY
}

\author{
Modernidade alimentar e consumo no segmento de máquinas de bebidas em cápsulas: \\ Um estudo a partir da teoria meios-fim
}

\begin{abstract}
RESUMO
A contemporaneidade gerou mudanças significativas na alimentação humana. O modo como a alimentação é percebida foi modificado, surgindo um novo conceito, o de modernidade alimentar. Os consumidores buscam além de apenas satisfazerem suas funções fisiológicas. Suas necessidades e objetivos são representados cognitivamente por meio de valores, entendidos aqui como estados finais que os consumidores almejam para si próprios. Esta pesquisa qualitativa e exploratória propôs compreender, através da teoria meios-fim, quais os valores que podem ser percebidos na relação de consumo de alimentos líquidos a partir da compra das máquinas de bebidas em cápsulas. Para tanto, procedeu-se com entrevistas em profundidade, a fim de identificar atributos, consequências e valores presentes nas decisões de compras dos consumidores. Utilizou-se a laddering como técnica de análise de conteúdo, pois ela permite maior representação de informações e relações agregadas à percepção dos consumidores, sendo os resultados dispostos em um mapa hierárquico de valores. Com auxílio do software LadderUx chegou-se a matriz de implicação e ao mapa hierárquico de valor. Dessa forma, tem-se como resultados os seguintes valores que influenciaram na decisão de compra das máquinas de bebidas em cápsulas: limpeza, independência, responsabilidade, afetividade, prazer e polidez. Cita-se a contribuição deste estudo para o entendimento desta nova tecnologia e as relações de consumo existentes. Em relação aos resultados práticos, estes podem ser aplicados em novas campanhas publicitárias e como estratégia de marketing.
\end{abstract}

Rodrigo Marçal Gandia

Universidade Federal de Lavras

romgandia@gmail.com

Amanda Pimenta Nascimento

Universidade Federal de Lavras

amanda_pimenta_1@hotmail.com

Isabela Murad

Universidade Federal de Lavras

isa.mrd@gmail.com

Luiz Henrique de Barros Vilas Boas

Universidade Federal de Lavras

luiz.vilasboas@ufla.br

Recebido em: 08/08/2019. Aprovado em: 22/07/2020.

Avaliado pelo sistema double blind review

Avaliador científico: Paulo Henrique Montagnana Vicente Leme

DOI: 10.48142/2238-68902019v21n1-3p94104

ABSTRACT

Contemporaneity has generated significant changes in food/human relations. The way food is perceived has been modified, and a new concept has emerged: the food modernity. People's needs and goals are represented cognitively through values, understood here as final states that consumers aim for themselves. This qualitative and exploratory research aimed to identify, under the perspective of the means-end theory, the relationships among the attributes, consequences, and values that motivate the consumption of coffee capsule machines. Laddering was used as a technique, since it allows more excellent representation of information and aggregated relations to the consumers' perception, and the results were arranged in a hierarchical map of values. With the help of the software LadderUx, we reached the matrix of implication and the hierarchical value map. Results showed that it is not the technology that modifies individuals' eating habits, but rather the relationships triggered by the modernity concepts. The transformations that occurred worldwide have changed peoples' lifestyles. In this context, the technology used in capsule machines contributes to the new modes of food consumption, through utilitarianism, quality, practicality, and the artifact itself (capsule machine).

Palavras-chave: Comportamento do Consumidor. Máquinas de Bebidas em Cápsulas. Teoria Meios-Fim.

Keywords: Beverage Capsules. Consumer Behavior. Modern Food Consumption. Chain Means-end. Laddering. 


\section{INTRODUCTION}

Socioeconomic and technological variables have had a significant impact on the supply and demand of products and services. Therefore, the consumer has become more demanding and recognizing his or her individual needs. It is in this context that the concept of food modernity is found, which is characterized by the historical moment in which individuals prone to changes occurring worldwide have less time to prepare food, given the other activities that are under their responsibility (FONSECA; SOUZA; FROZI; PEREIRA, 2011).

This new scenario reflects on how individuals are feeding. The consumer relationships with individual portions have narrowed, and food is no longer used simply to fulfill the physiological functions. By identifying these new consumers, the industry has also targeted an audience that spends less time doing things.

Thus, as part of the changes in food consumption, other ways of preparing and distributing food appear, together with the development of new eating habits, causing the industry to develop foods directed to consumers' current demands, with a particular focus on reducing food consumption' feeding time (VIECELLI, 2019). An example is the insertion of reduced-size packages similar to the individual portion.

In this sense, capsule machines arise at a time of changing eating habits. Based on a model established by Nespresso, capsule machines were introduced in 1986, with the company aiming to reach new markets, innovating exclusively in the coffee segment (MARTINS, 2013). Following the success of the Nespresso business model, other brands have begun investing in research and offering other capsule drinks due to the high growth rate.

Therefore, drinks in capsules become a way of adding value to the product. According to Conceição et al. (2019), in the case of coffee, there are several ways of adding value to the product, which runs through the entire agro-industrial chain, from the production of the bean to the final commercialization, as for the capsules, the process of adding value occurs in the industrial phase. According to a study by Euromonitor (2017), Brazil has become the largest coffee market globally, with $15 \%$ of the total volume. As a result, coffee consumption has grown steadily, with the market dominated by roasted coffee and ground, but the future still depends on new types of coffee like capsules. According to a survey questionnaire, even though ground coffee still accounts for the majority, more than $60 \%$ of respondents consumed coffee in capsules. It highlights the importance of analyzing the new habits of consumers regarding the use of beverage machines in capsules. Although it is still an emerging market, there is an expectation of significant growth, as individuals are experiencing changes in habits food.

Given the aforementioned, understanding the factors that influenced the success of business models established by capsule machines is based on understanding the management characteristics involved in these models and the understanding of their users' consumption behavior. Consumer behavior is characterized by mental and emotional activities involved in selecting, purchasing, and using products/services to satisfy the needs and desires (RICHERS, 1984). For Costa et al. (1999), personality characteristics influence consumers' responses to new products and those obtained by new technologies. In this way, understanding each individual's characteristics is fundamental for the introduction of new products in the current competitive market.

As one of the factors affecting individuals' way of thinking and acting, personal values have received considerable attention from marketing scholars, which can be seen in the growing number of studies that seek to explain how values influence behavior (JEUNON, 2005). In order to achieve the perception of the personal values of capsule machine users, it is necessary to follow a path initiated at more concrete levels, their attributes, and perceived benefits. Gutman (1991) states that the said structure of analysis allows the researcher to construct an ordering among elements to unravel how the relationship between attributes, consequences, and values is manifested in the consumer's abstraction.

Thereby, the following question guides this study: is there a relationship between modern food consumption and capsule machines? To obtain answers, the general aim is to identify, under the perspective of the means-end theory, the relationships between the attributes, consequences, and values that motivate the consumption of capsule machines.

This paper addressed two main contributions; First, we tried to understand the relationship between the motivations perceived by consumers of capsule machines and the precepts established by the modernity concept. Second, verifying whether the technology of capsule machines is modifying consumption behavior.

This study is structured in five parts, besides this introduction. The first part, the theoretical framework of this article, provides information about the food modernity and the means-end theory; the second part discusses the used methodology; the third part presents the results and discusses the data; subsequently, there are the final considerations, and then the references. 


\section{THEORETICAL BACKGROUND}

\subsection{Food Modernity and Food Consumption}

The industrialization process, along with a series of technical-scientific findings, has contributed significantly to the changes in people's lifestyles, especially concerning the eating habits of the Brazilian population. In the recent decades, the change in eating habits around the world in an attempt to add time and practicality to the modern lifestyle has been noticeable (FRANÇA; MENDES; ANDRADE; RIBEIRO; PINHEIRO, 2012).

The concept of food modernity synthesizes and represents the impacts that food has suffered before social, economic, and cultural changes in contemporary society (FONSECA et al., 2011). According to these authors, this concept can be understood as a historical moment in which numerous changes occur in the food system in the contemporaneity context. Furthermore, the impacts caused by the relationship between modern consumers and food are highlighted since they are directly associated with consumer's desires and needs.

Data from the National Survey conducted by Fiesp and Ital in the Brazil FoodTrends 2020 project point to some factors that influence food consumption, such as the growth of urban population superior to the rural population; the age and family structure and the insertion of women in the labor market; and higher levels of education, information, and cultural exchange. These factors are derived from contemporaneity, which undoubtedly brought new configurations to the world of work (FIESP, ITAL, 2010). The marks of globalization and industrialization, the expansion of trade, economies of scale, the feminization of society, and the new relations between the individual and the collective are aspects that have influenced the feeding of modern consumers, thus emerging new relationships with food (FONSECA et al., 2011).

Fonseca et al. (2011) emphasize that consumers' desire to love allows associating food, although unconsciously with expressions such as virility, strength, lightness, and modernity. Thus, it is believed that consumers associate new psycho-affective perceptions with food. Although it is closely related to the individual's physiological functions, it is recognized that this physiological function in modern society has acquired other meanings, such as those cited above.

About the phenomenon of the society's feminization in the 1960s and 1970s and the insertion of women in the labor market, Fischler (1995) points out that it has generated profound changes in family relations, which can be seen in the division of family tasks among the other household members. These new family structures have promoted an individualization of the family regarding their eating habits, making the rest of the family more autonomous to decide their food (GERDING, 1996).

For França et al. (2012), to try to adapt the food to the fast pace of everyday life, consumer choices and habits began to point to foods more appropriate for this lifestyle, incorporating more rapid and practical habits. In this context of optimization of the time spent with tasks, it arises the question of food consumption being done both in the family space and outside it. The individual portions began to take the place of larger quantities that were intended for the family. These individual portions can be evaluated by consumers as practical, economical, sustainable, and safe, thus avoiding waste, which are meanings attributed through a consumption relationship (FONSECA et al., 2011).

The new demands and trends of food consumers include five main aspects: sensorially and pleasure (premium, ethnic, gourmet foods); health and well-being (light/diet, energy, fortified products); convenience and practicality (ready meal, microwave products); reliability and quality (guarantee of origin, quality seals); and sustainability and ethics (recyclable packaging, environmental seals) (FIESP, ITAL, 2010).

According to the report prepared by the Euromonitor International for the Brazilian Coffee Industry Association (ABIC), published in November 2015, the consumer is looking for products more pertinent to his or her routine and his or her budget, highlighting the practicality of the capsule, being able to serve mono doses, especially on in-home consumption.

Fischler (1995) points out that food has acquired a variety of forms. One of these forms is drinks, which are essential for the growth of a country's income, given that "people stop drinking only water and start to consume other products with higher added value" (CIPOLLA et al., 2002, p. 282).

In this way, this study seeks to discuss new meanings regarding the influence of modernity and its relationship with food consumption, more specifically through the relationship between personal values and consumption, from the purchase of capsule machines. Thus, the next session seeks to elucidate the inherent precepts to values as a purchase decision and aspects related to the means-end theory.

\subsection{Means-end Theory and Values as a Purchase Decision}

The means-end theory is linked to research on value for the customer. "This theory is based on the "micro" approach of analysis that characterizes a psychological perspective of consumer behavior interpretation and focuses on the links between the attributes that exist in the products 
(the means), the consumer consequences provided by the attributes and personal values (the ends) that these consequences reinforce" (REYNOLDS; GUTMAN, 1988, p. 11).

The means-end chain model presupposes that the "means" are the products with which people are involved, and the ends are the valued states of existence. However, to reach these values, it is necessary to trace a path that begins in the identification of attributes, goes through the consequences until arriving at the values, i.e., the product attributes take the consequence that, in turn, help to reach the personal values of each individual (OLIVEIRA; IKEDA, 2008). The same authors affirm that "the product characteristics gain relevance or meaning for consumers due to their association with the consequences of their use and hence reaching personal values" (OLIVEIRA; IKEDA, 2008, p.4). Understanding these elements (attributes, consequences, and values) in consumer contexts allows understanding the connection between product knowledge and consumer self-knowledge and can be interpreted in an expanded way, as shown in Figure 1.

Rokeach (1968/69, p. 551) defines a value system as "nothing more than a hierarchical arrangement of values, an orderly ranking of values along a continuum of importance." In his studies, he identified a total of 36 values in his value Survey (RVS). These were divided into two groups. The first shows the personal instrumental valuesand the second personal terminal values. A set is composed of 18 terminal values or desired end-states of existence, and the other is formed by 18 instrumental values or preferred modes or behaviors.

According to Blackwell, Miniard, and Engel (2005), people have the same values but differ in the importance attributed to them. Moreover, because they play a central role in cognition, values provide a robust basis for understanding consumer behavior within several different cultures.

The concept of the means-end chain offers marketing managers a way to link product consumption to the ultimate consumer's desire (GUTMAN, 1982). Thus, value studies help understand consumer behavior, providing support for segmentation, product planning, and promotional strategies (GUTMAN, 1982).

For the construction of this study, the perspective proposed by Schwartz (1992) and the Rokeach value survey (1981) were used based on the means-end theory, being used from the definition of its constructs and in the codification of values (instrumental and terminal) identified from field surveys.

\section{RESEARCH METHODOLOGY}

This study has a qualitative and exploratory nature and used scaling and hierarchical value mapping techniques, which compose the technique called laddering, as suggested by Reynolds and Gutman (1988). The laddering follows, as a methodological basis, the means-end theory, which assumes that the consumer has the perception of attributes, consequences, and values related to a product or brand (REYNOLDS; GUTMAN, 1988).

Data were collected during 2015 through individual in-depth interviews, based on procedures to identify attributes suggested by Reynolds and Gutman (1988). A total of 16 interviews were conducted, from which five were face-to-face and 11 through Skype software, with an average time of 26 $\min$. The interviewees' selection was through groups of coffee lovers' capsule machines on Facebook, for convenience, based on a demonstration of interest on the part of the interviewee to participate in the research, and the snowball technique. From the demonstration of interest, consumers were subjected to the following selection criteria: a) to have purchased a capsule machine, regardless of brand or model; (b) to be consumers of capsule products (coffee and its derivatives for at least three months; (c) to maintain a consumption periodicity of the capsules at least once a week; d) to have purchased capsules at least three months before the day of the in-depth interview, and e) are willing to go through a recorded interview.

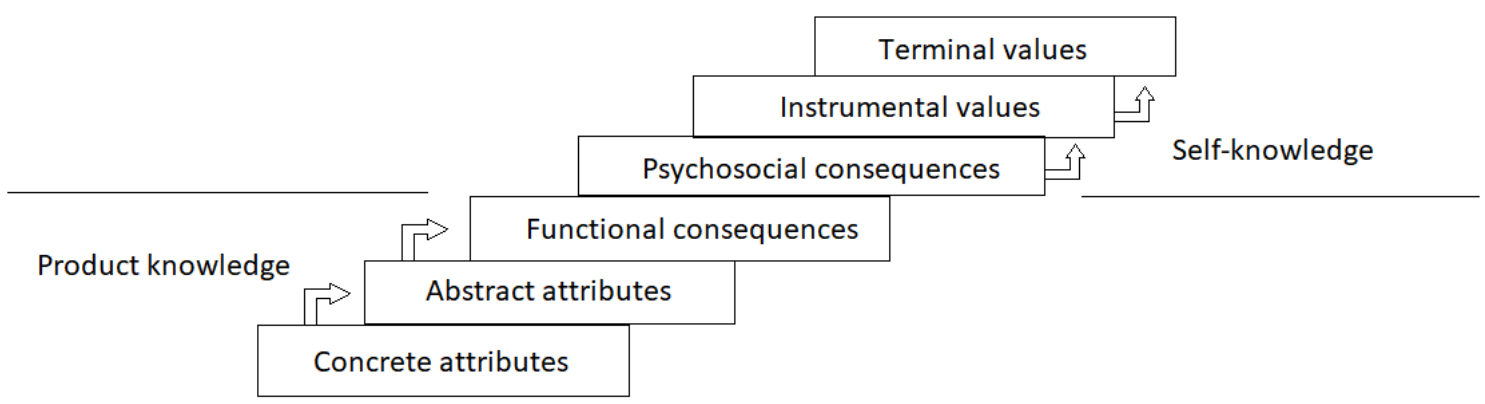

FIGURE 1 - Connection between product knowledge and self-knowledge through the means-end chain Source: Adapted from Walker \& Olson (1991)

Organizações Rurais \& Agroindustriais, Lavras, v. 21, n. 1-3, p. 94-104, 2019 
After the data collection, the interviews were transcribed, and the scale construction started from the semantic processes of content analysis (BAUER, 2002), following the saturation criterion (GUERRA, 2006). The result of this stage was a set of related elements (keywords) in an A-C-V sequence, which expresses the interviewees' perception (OLIVEIRA; IKEDA, 2008).

Subsequently, with the LadderUx software's help, the next stages were the construction of the implication matrix and the hierarchical value map (HVM). Finally, in order to understand which of these identified chains showed dominant perceptions, an individual analysis was performed in each of the chains identified in the HVM based on the methodology proposed by Vilas Boas (2005), presented in the next section.

\section{RESULTS AND DISCUSSION}

HVMand perception of dominant chains were obtained from laddering, which allowed the identification of 33 elements (Table 1), being eight attributes (four concrete and four abstract), 17 consequences (11 functional and six psychosocial), and seven values (four instrumental and three terminals).

\subsection{Implication Matrix}

Based on the elements identified from the consumers' perception of capsule machines, the next step was constructing the implication matrix, developed using the LadderUx software (Table 2).

The implication matrix consists of columns and rows, one column and one row for each element coded sequentially, based on the assigned code numbering, being the basis for the HMV construction. According to Reynolds and Gutman (1988), direct links correspond to those in which one element is directly connected. The cells are filled with the number of direct relationships on the left and the number of indirect relationships on the right, i.e., an accounting of how many times an element has received direct (left-cell) or indirect (right-cell), representing a quantification of qualitative data.

\subsection{Hierarchical Value Map (HVM) and Chains of the Dominant Perception}

The next stage of laddering is characterized by the construction of the hierarchical value map (HVM). Reynolds and Gutman (1988, p. 23) point out that the purpose of HVM is to "map hierarchical relationships and interconnect all significant chains on a map in which all relations are exposed [...] resulting in a map that includes all the relevant relationships easily to read and interpret".

TABLE 1 - Summary list of codes: attributes, consequences, and values

\begin{tabular}{|c|c|}
\hline Attributes (concrete) & Consequences (psychosocial) \\
\hline 1. Variety of drinks & 20. Receiving with warmth/welcome visits \\
\hline 2. Capsule machine & 21. It allows me taking care of the environment \\
\hline 3. Monodose & 22. I feel special about having a machine of this brand \\
\hline 4. Product (capsule) & $\begin{array}{l}\text { 23. Meet my needs/I am satisfied } \\
\text { 24. It allows me to attend the boutique of the store. }\end{array}$ \\
\hline \multicolumn{2}{|l|}{ Attributes (abstract) } \\
\hline 6. Brand & 25. It is suitable for health \\
\hline 7. Practicality (easiness and speed) & 26. Harmonization \\
\hline \multicolumn{2}{|l|}{ 8. Quality } \\
\hline Consequences (functional) & 27. Responsibility (commitment; to be trustworthy) \\
\hline 9. I have more drink options & 28. Affectivity (affection, tenderness) \\
\hline 10. It allows me avoiding waste & 29. Cleaning (cleanliness and tidiness) \\
\hline 11. I have punctuality & 30. Independence (self-reliance, self-sufficiency) \\
\hline \multicolumn{2}{|l|}{ 12. It allows me doing other things while the drink is getting ready } \\
\hline 13. I have a specialty product (different and reliable) & Values (terminals) \\
\hline 14. Cost-benefit & 31. Freedom (independence, freedom of choice) \\
\hline 15. Keep coffee properties & 32. Pleasure (a life with joy and pleasure) \\
\hline 16. It allows me always having the same drink (standardized) & 33. Politeness (courtesy; good manners) \\
\hline 17. I have agility and easiness in the preparation & \\
\hline 18. Product mobility & \\
\hline 19. Attractive commercial & \\
\hline
\end{tabular}

Source: Elaborated by the authors (2016)

Organizações Rurais \& Agroindustriais, Lavras, v. 21, n. 1-3, p. 94-104, 2019 
TABLE 2 - Implication matrix

\begin{tabular}{|c|c|c|c|c|c|c|c|c|c|c|c|c|c|c|c|c|c|c|c|c|c|c|c|c|c|c|c|c|c|c|}
\hline cód & 12 & 23 & 3 & 4 & 5 & 6 & 7 & 8 & 9 & 10 & 11 & 12 & 1314 & 15 & 16 & $17 \quad 18$ & 19 & 2021 & 22 & 23 & 2425 & 26 & 27 & 28 & 29 & 30 & 31 & 32 & 33 & sum \\
\hline 1 & & & & & & & & & $9 \mid 0$ & & & & 0 & & & & & $0 \mid 8$ & & $0 \mid 1$ & & $0 \mid 1$ & & $0 \mid 6$ & & & $0 \mid 4$ & $0 \mid 3$ & $0 \mid 2$ & $9 \mid 26$ \\
\hline 2 & & & & & & & & & & $1 \mid 1$ & & $8 \mid 1$ & $0 \mid 2$ & & & $0 \mid \begin{array}{lll} & 0 \mid 1\end{array}$ & $1 \mid 0$ & $0 \mid 2$ & $1 \mid 1$ & $0 \mid 5$ & & & $0 \mid 1$ & $0 \mid 3$ & $0 \mid 1$ & $0 \mid 1$ & $0 \mid 2$ & $0 \mid 5$ & $0 \mid 1$ & $11 \mid 29$ \\
\hline 3 & & & & & & & & & & $3 \mid 0$ & & & & $0 \mid 1$ & $2 \mid 0$ & $0 \mid 1$ & & $0 \mid 1$ & & $0 \mid 2$ & & & & $0 \mid 1$ & $0 \mid 2$ & $0 \mid 2$ & & $0 \mid 2$ & $0 \mid 1$ & $5 \mid 13$ \\
\hline 4 & & & & & & & & & $2 \mid 0$ & $1 \mid 2$ & & & $0 \mid 1$ & $2 \mid 1$ & & & & $1 \mid 1$ & & & & $0 \mid 1$ & $0 \mid 1$ & & $0 \mid 4$ & & $0 \mid 2$ & $0 \mid 2$ & & $6 \mid 15$ \\
\hline 5 & & & & & & & & & & & & & $5 \mid$ & & & & & & & $0 \mid 4$ & & & & & & $0 \mid 5$ & & $0 \mid 1$ & & $5 \mid 10$ \\
\hline 6 & & & & & & & & & $1 \mid 0$ & & & & $3 \mid 2$ & & $1 \mid 2$ & $0 \mid 1$ & $1 \mid 0$ & $0 \mid 1$ & $0 \mid 2$ & $1 \mid 0$ & $2 \mid 4$ & & $0 \mid 4$ & $0 \mid 2$ & $0 \mid 1$ & $0 \mid 1$ & $0 \mid 1$ & $0 \mid 4$ & $0 \mid 2$ & $9 \mid 27$ \\
\hline 7 & & & & & & & & & & 610 & $1 \mid 4$ & $5 \mid 4$ & & $0 \mid 1$ & $0 \mid 4$ & 215 & & $0 \mid 4$ & & & & & $0 \mid 4$ & $0 \mid 5$ & $0 \mid 2$ & $0 \mid 2$ & $0 \mid 2$ & $0 \mid 4$ & $0 \mid 4$ & $14 \mid 45$ \\
\hline 8 & & & & & & & & & & & & & $6 \mid 1$ & $2 \mid 0$ & $3 \mid 7$ & & & & & $3 \mid 11$ & $0 \mid 1$ & & $0 \mid 2$ & $0 \mid 2$ & & $0 \mid 3$ & & $0 \mid 11$ & $0 \mid 2$ & $14 \mid 40$ \\
\hline 9 & & & & & & & & & & $0 \mid 1$ & & & $1 \mid$ & $1 \mid 0$ & $1 \mid 0$ & & & $7|1 \quad 1| 0$ & $0 \mid 1$ & $0 \mid 1$ & $0 \mid 1$ & $1 \mid 0$ & & $0 \mid 6$ & $0 \mid 2$ & & $0 \mid 5$ & $0 \mid 3$ & $0 \mid 2$ & $12 \mid 23$ \\
\hline 10 & & & & & & & & & & & $1 \mid 0$ & $5 \mid 0$ & & $3 \mid 1$ & $0 \mid 1$ & $1 \mid 1$ & & $3 \mid 1$ & & $0 \mid 1$ & & $1 \mid 0$ & $0 \mid 2$ & $0 \mid 3$ & $3 \mid 2$ & $0 \mid 1$ & $0 \mid 1$ & $0 \mid 5$ & $0 \mid 2$ & $17 \mid 21$ \\
\hline 11 & & & & & & & & & & & & $2 \mid 0$ & & & & $2 \mid 1$ & & $0 \mid 1$ & & & & & $2 \mid 0$ & $0 \mid 1$ & $1 \mid 0$ & & $0 \mid 1$ & $0 \mid 1$ & $1 \mid 0$ & $8 \mid 5$ \\
\hline 12 & & & & & & & & & & & & & $1 \mid 1$ & & $1 \mid 2$ & 710 & & $1 \mid 4$ & $1 \mid 0$ & $3 \mid 1$ & & & $1 \mid 2$ & $0 \mid 6$ & $0 \mid 1$ & $0 \mid 2$ & $0 \mid 4$ & $1 \mid 4$ & $0 \mid 5$ & $16 \mid 32$ \\
\hline 13 & & & & & & & & & & & & & & $1 \mid 0$ & $5 \mid 0$ & & & & $2 \mid 0$ & $5 \mid 3$ & $3 \mid 1$ & & $2 \mid 3$ & $1 \mid 3$ & & $1 \mid 3$ & $0 \mid 1$ & $0 \mid 7$ & $0 \mid 5$ & $20 \mid 26$ \\
\hline 14 & & & & & & & & & & & & & & & & & & & & $4 \mid 0$ & & & & & & $1 \mid 4$ & $1 \mid 0$ & $0 \mid 1$ & & $6 \mid 5$ \\
\hline 15 & & & & & & & & & & & & & & & $3 \mid 0$ & $1 \mid 0$ & & & & $0 \mid 2$ & & $0 \mid 1$ & $0 \mid 1$ & & $1 \mid 1$ & $0 \mid 1$ & $0 \mid 1$ & $0 \mid 4$ & & $5 \mid 11$ \\
\hline 16 & & & & & & & & & & & & & & & & $2 \mid 0$ & & $1 \mid \begin{array}{ll}0 & 1 \mid 0\end{array}$ & $1 \mid 0$ & $10 \mid 2$ & $1|21| 0$ & & $1 \mid 1$ & $1 \mid 3$ & $0 \mid 1$ & $2 / 4$ & $0 \mid 1$ & $1 \mid 10$ & $0 \mid 4$ & $22 \mid 28$ \\
\hline 17 & & & & & & & & & & & & & & & & & $1 \mid 0$ & $2 \mid 1$ & & & & & $1 \mid 1$ & $1 \mid 3$ & $0 \mid 2$ & $0 \mid 1$ & $1 \mid 2$ & $1 \mid 3$ & $0 \mid 2$ & $7 \mid 15$ \\
\hline 18 & & & & & & & & & & & & & & & & & & & $1 \mid 0$ & $1 \mid 0$ & & & & & & & & $0 \mid 1$ & & $2 \mid 1$ \\
\hline 19 & & & & & & & & & & & & & & & & & & & & & & & & $1 \mid 1$ & & & & $0 \mid 2$ & & $1 \mid 3$ \\
\hline 20 & & & & & & & & & & & & & & & & & & & & $1 \mid 0$ & & $1 \mid 0$ & & $12 \mid 0$ & $0 \mid 2$ & & $1 \mid 3$ & $0 \mid 3$ & $0 \mid 5$ & $15 \mid 13$ \\
\hline 21 & & & & & & & & & & & & & & & & & & & & & $1 \mid 0$ & & & & $2 \mid 1$ & & $0 \mid 1$ & & & $3 \mid 2$ \\
\hline 22 & & & & & & & & & & & & & & & & & & & & $0 \mid 1$ & $1 \mid 0$ & & $1 \mid 0$ & $0 \mid 1$ & & & $0 \mid 1$ & $0 \mid 1$ & $0 \mid 1$ & $2 \mid 5$ \\
\hline 23 & & & & & & & & & & & & & & & & & & & & & $1 \mid 0$ & & $3 \mid 1$ & $2 \mid 0$ & & $10 \mid 0$ & $0 \mid 1$ & $8 \mid 10$ & $0 \mid 2$ & $24 \mid 14$ \\
\hline 24 & & & & & & & & & & & & & & & & & & & & & & & $1 \mid 1$ & $1 \mid 0$ & $1 \mid 0$ & $0 \mid 1$ & & $0 \mid 2$ & $0 \mid 2$ & $3 \mid 6$ \\
\hline 25 & & & & & & & & & & & & & & & & & & & & & & & & & & & & $0 \mid 1$ & & $0 \mid 1$ \\
\hline 26 & & & & & & & & & & & & & & & & & & & & & & & & & & & $0 \mid 1$ & $1 \mid 0$ & & $1 \mid 1$ \\
\hline 27 & & & & & & & & & & & & & & & & & & & & & & & & & & & $1 \mid 0$ & 610 & $1 \mid 0$ & $8 \mid 0$ \\
\hline 28 & & & & & & & & & & & & & & & & & & & & & & & & & $2 \mid 0$ & & $3 \mid 0$ & $4 \mid 1$ & $10 \mid 0$ & $19 \mid 1$ \\
\hline 29 & & & & & & & & & & & & & & & & & & & & & & & & & & & $2 \mid 0$ & $1 \mid 0$ & & $3 \mid 0$ \\
\hline 30 & & & & & & & & & & & & & & & & & & & & & & & & & & & $2 \mid 0$ & $8 \mid 0$ & & $10 \mid 0$ \\
\hline 31 & & & & & & & & & & & & & & & & & & & & & & & & & & & & $1 \mid 0$ & & $1 \mid 0$ \\
\hline 32 & & & & & & & & & & & & & & & & & & & & & & & & & & & & & & $0 \mid 0$ \\
\hline 33 & & & & & & & & & & & & & & & & & & & & & & & & & & & & & & $0 \mid 0$ \\
\hline
\end{tabular}

Source: Elaborated by the authors with the aid of LadderUx software (2016)

One of the factors that must be considered in the HVM construction is the cut-off point (Reynolds and Gutman, 1988), where a minimum level is established to which the relationships would be considered, in order to obtain greater representativeness. The cut-off point established for this study was the 3, i.e., only the attributes, consequences, and values with three or more direct and indirect relationships among elements were illustrated in the HVM. From the established cut-off point, 43 chains consisting of seven attributes (three concrete and four abstract), 12 consequences (eight functional and four psychosocial), and seven values (four instrumental and three terminals) were observed, with 696 connections, being 278 direct and 418 indirect (Figure 2).

Although the most representative chains are indicated in the HVM, there are chains of dominant perception, i.e., those represented with the highest number of direct and indirect relationships and hence characterized as the strongest. Thus, the methodology proposed by Vilas Boas (2005) was adopted in order to identify the chains of dominant perception. According to the author, to identify the strongest chains without excluding important chains due to their smaller number of elements, it is necessary to initially separate the chains according to the number of constituent elements. Subsequently, the analysis must be performed according to the varied sizes presented by the HVM chains. Thus, among the 43 chains presented in HVM, five different chain sizes were identified, being composed of two, three, four, five, and six elements.

After grouping the chains by blocks, chains were analyzed individually. The direct and indirect relationships of each of its elements were counted and, after performed the sum of the relationships in each chain, the results of all 
the chains were added according to its number of elements, dividing later this value by the number of chains of each block, thus finding an average value of relationships. This average value was considered the cut-off point, i.e., chains with a sum of direct and indirect relationships below this cut-off point were not considered dominant, and chains with values equal to or above the cut-off point were considered as orientation chains of dominant perception. From this analysis, 21 chains of dominant perception were evidenced (Table 3).

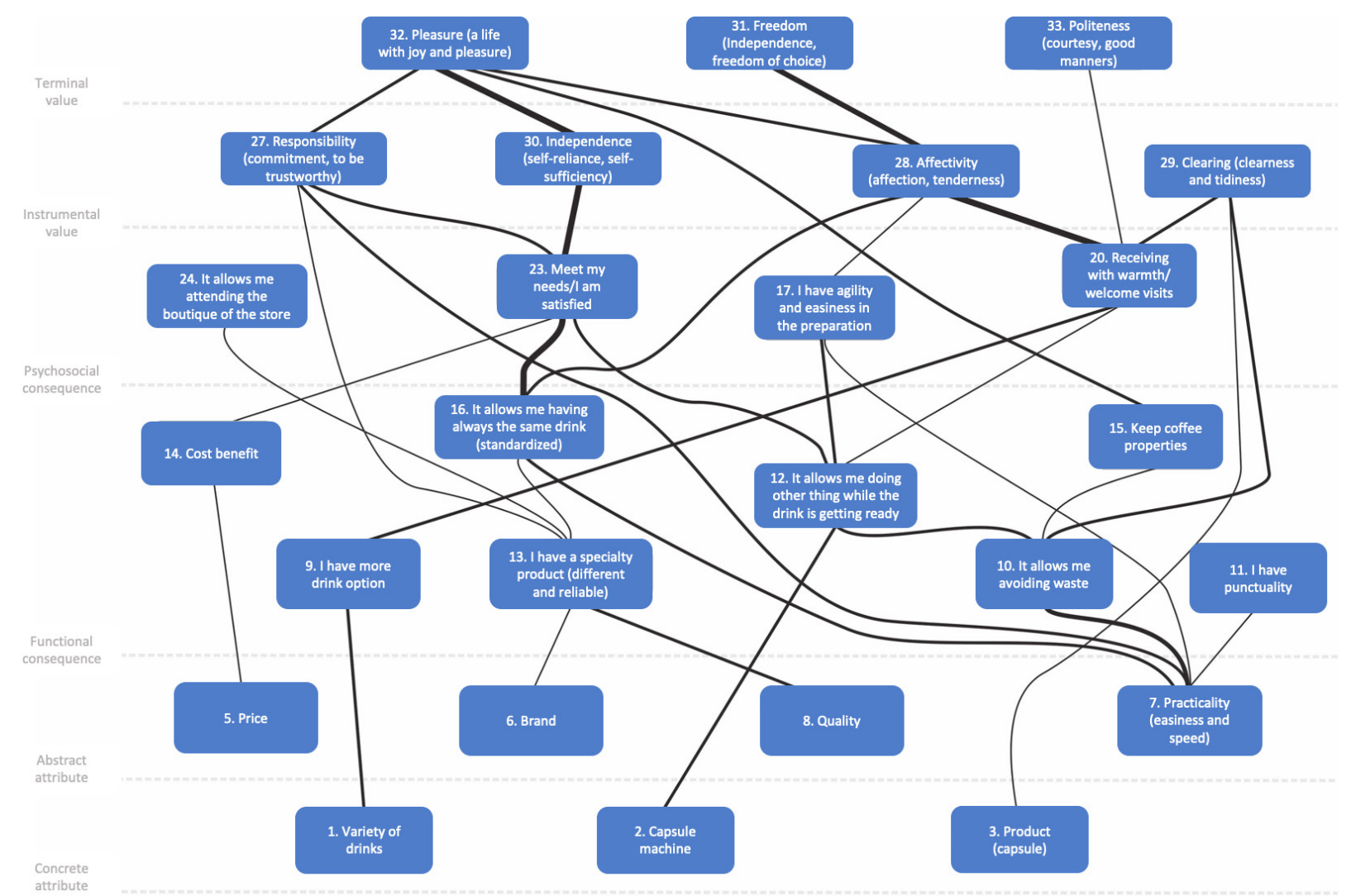

FIGURE 2 - Hierarchical value

Source: Adapted by the authors based on data extracted from the LadderUx software

TABLE 3 - Chains of the dominant perception

\begin{tabular}{|c|c|c|c|c|c|}
\hline \multirow{9}{*}{$\begin{array}{l}\text { Description of elements of the } \\
\text { chain of dominant perception (by } \\
\text { code) }\end{array}$} & \multirow[t]{5}{*}{2 Elements } & \multirow[t]{4}{*}{3 Elements } & 4 Elements & 5 Elements & 6 Elements \\
\hline & & & & $05-14-23-30-32$ & \\
\hline & & & $08-13-27-32$ & $08-13-16-28-32$ & \\
\hline & & & $07-16-28-33$ & $07-16-23-30-32$ & $08-13-16-23-30-32$ \\
\hline & & $06-13-24$ & $07-16-28-32$ & $02-12-23-30-32$ & $08-13-16-23-27-32$ \\
\hline & \multirow{4}{*}{$07-11$} & $07-27-32$ & $07-17-28-33$ & $02-12-23-27-32$ & $06-13-16-23-30-32$ \\
\hline & & & $07-17-28-32$ & $02-12-20-28-33$ & $06-13-16-23-27-32$ \\
\hline & & & $01-09-20-29$ & $01-09-20-28-33$ & \\
\hline & & & & $01-09-20-28-32$ & \\
\hline
\end{tabular}

Source: Elaborated by the authors (2016)

Organizações Rurais \& Agroindustriais, Lavras, v. 21, n. 1-3, p. 94-104, 2019 
In Figure 2, it is observed traces among elements from each chain, where the line thickness visually identifies the amount of relationships present between each element, i.e., thicker lines show a greater number of direct or indirect relationships.

Moreover, in the HVM analysis, it can be noticed the presence of six attributes originating from the chains of dominant perception, being two concrete; (01) Variety and (02) Capsule machines, and four abstract; (05) Price; (06) Brand; (07) Practicality, and (08) Quality. Regarding the consequences, 11 were found, being eight functional; (09) I have more drink options; (11) I have punctuality; (12) It allows me doing other things while the drink is getting ready; (13) I have a special, different and reliable product; (14) Cost benefit; (16) It allows me having always the same drink and (17) I have agility and easiness in the preparation, and three psychosocial; (20) Receiving with warmth/welcome visits; (23) Meet my needs and (24) It allows me attending to the boutique of the store. Finally, six values, being four instrumentals; (29) Cleaning; (30) Independence; (32) Responsibility, and (33) Affectivity, and two terminals; (32) Pleasure and (33) Politeness.

The abstract attribute (07) Practicality was the most recurrent among the dominant perception chains, being in seven from the 21 chains found, followed by (08) Quality, and by the concrete attribute (02) Capsule machines (four times each). This fact demonstrates that the convenience and practicality of obtaining a capsule machine is one of the factors perceived as a determinant in the orientation of product purchase as well as the quality observed by the users and the fact that they have the artifact (capsule machines), which is understood as something that draws attention to the interviewees' guests. This fact corroborates the trends established by the BFT 2020 report, which indicates that quality, convenience, and practicality are precursors of modern food behavior (FIESP and ITAL, 2010).

Among the functional consequences, (16) It allows me always having the same drink (standardized), was the one with the highest incidence (recurrent in eight chains), followed by (13) I have a unique, different, and reliable product. This fact demonstrates that users of capsule machines show a perception related to the confidence and standardization of the products. The fact that confidence and standardization are perceived as consumer benefits is directly related to modern food.

The psychosocial consequence of higher recurrence, appearing eight times, is (23) Meet my needs; I am satisfied. It should be noted that consumers of capsule drinks have established a greater number of functional consequences over the psychosocial ones, i.e., a feeling perceived to be more utilitarian than hedonic when it comes to capsule machines. However, the latter cannot be ruled out by the existence of evidence of psychosocial consequences in the results. Gerding (1996) proposed the new family structures suggest the need for autonomy of individuals, being this utility response to the needs of consumers of capsule machines.

Regarding the values, it is noted that the instrument (28) Affectivity stands out (recurrent in eight chains), demonstrating a feeling of willingness to receive with affection the guests and their families. The terminal value (32) Pleasure is the most recurrent (14 times), evidencing a feeling in tasting the drink, having the machine, and being able to offer to the people. From the value classification of Schwartz (1992), the value of "pleasure" is related to hedonism, which is considered by the author as pleasure, fun, individual and momentary values situated within the dimensions of "self-improvement" and "openness to change." This fact evidences a more individual positioning of capsule machine users that seek a momentary feeling of filling from the product use.

Still based on Figure 2, several paths can be perceived as responsible for the acquisition of a capsule machine and, among the presented chains, the chain 08-13-16-2330-32 was identified with a higher perception index in the study. In this chain, (08) Quality perceived leads to the functional benefits of (13) I have a unique, different and reliable product and (16) It allows me always having the same drink (standardized), unleashing the psychosocial consequence of (23) My needs/I am satisfied, related to the instrumental value of (30) Independence and finally to the terminal value of (32) Pleasure. This chain illustrates the main path perceived by capsule machine users. Corroborating with this fact, Martins (2013) states that capsule machines have become a successful product with a high growth trend, as they offer to coffee connoisseurs the opportunity to have espresso without leaving home only.

\section{FINAL CONSIDERATIONS}

The concepts of food modernity suggest changes in consumer behavior. In this context, capsule machines arise in a time of transition among eating habits of a society that shows signs of new needs. Consumers' lack of time, motivated by the feminization of society (FISHLER, 1995), is one of the most evident factors, being this indicated with higher recurrence in users' perception (practicality). However, practicality does not confer the success of capsule machines, 
but rather the composition of other attributes perceived by consumers, such as quality and the own artifact (capsule machine). This is evident with the failure of similar products that, although practical as a primordial characteristic, do not deliver quality, such as soluble coffee. Teixeira (2014 p. 105) states that "soluble coffee, although it has brought practicality and portability as an advantage, has failed to deliver the aroma and flavor that was appreciated by consumers of coffee brewed in the cloth filter."

In this way, the relationships perceived by the consumers of capsule machines are compatible with the precepts established by the food modernity, since they deliver not only the practicality, but also other characteristics valued by the consumer. Carrêlo (2014) states that capsule machines offer a solution that allows consumers to enjoy quality drinks conveniently and in a practical way in the comfort of their homes, as these attributes are evidenced as predominant in this study.

As a first contribution, to understand the relationships between modern food consumption and capsule machines, our theoretical results, shows that the study's contribution is besides the perception of consumption relationships among users. Concerning the practical results, the results can aid in the marketing strategy of companies inserted in the capsule market, such as market segmentation, information for new product development, communication, and advertising, which are possible strategic determinants existing as potential from the HVM.

Thus, as a second contribution, the study results show that it is not the technology that is modifying individuals' eating habits, but rather the relationships triggered by the modernity concepts. The transformations that occurred worldwide have changed people's way of life. In this context, the technology used in capsule machines contributes to the new modes of food consumption, through utilitarianism, quality, practicality, and the own artifact (capsule machine). Notwithstanding this, the relationships perceived by Schwartz's value scale (1992) show hedonic relationships originating from the values attributed to the product as pleasure, fun, individual and momentary values.

In order to proceed with this research, as a future agenda, we suggest the expansion of this study from the evidenced variables based on chain elements for a research universe in the national scenario to quantify the results observed here. Moreover, it is essential to expand this work from a quantitative perspective, such as "hard laddering technique" (ARES, GIMÉNEZ, GAMBARO, 2008). For instance, it is possible to correlate the values to variables such as purchase intention, price, fidelity, and brand relevance.

\section{REFERENCES}

ASSOCIAÇÃO BRASILEIRA DA INDÚSTRIA DE CAFÉ. Tendências do mercado de café: Relatório customizado preparado pelo Euromonitor International para Associação Brasileira da Industria de Café. 2015. Disponível em: www.abic.com.br. Acesso em: 10 out. 2016.

ARES, G.; GIMÉNEZ, A.; GÁMBARO, A. Understanding consumers' perception of conventional and functional yogurts using word association and hard laddering. Food Quality and Preference, Prefer., v. 19, n. 7, p. 636-643, 2008.

BAUER, M. W. Análise de conteúdo clássica: uma revisão. Pesquisa qualitativa com texto, imagem e som: um manual prático. Petrópolis: Vozes, p. 189-217, 2002.

BLACKWELL, R. D.; MINIARD, P. W.; ENGEL, J. F. Comportamento do consumidor. São Paulo: Pioneira Thomson Learning, 2005.

CARRÊLO, M. V. P. A Influência da marca Nespresso no comportamento de compra da máquina e cápsulas de café. 2014. 421 f. Dissertação (Mestrado em Publicidade e Marketing) - Escola Superior de Comunicação Social, Lisboa, 2014.

CIPOLLA, L. E.; NEVES, M. F.; AMARAL, T. M. Mercado brasileiro de alimentos líquidos nos anos 90 e perspectivas futuras. In: Congresso Brasileiro de Economia e Sociologia Rural, Equidade e Eficiência na Agricultura Brasileira, 40, 2002, Passo Fundo. Anais... Passo Fundo, 2002.

CONCEIÇÃO, J. C. P. R.; ELLERY JUNIOR, R.; CONCEIÇÃO, P. H. Z. Cadeia Agroindustrial do Café no Brasil: agregação de valor e exportação. Boletim de Economia e Política Internacional (BEPI), Brasília, n. 24, Jan./Abr. 2019.

Costa, M. C.; DelizA, R.; Rosenthal, A. Revisão: Tecnologias não convencionais e o impacto no comportamento do consumidor. Boletim do Centro de Pesquisa de Processamento de Alimentos, Curitiba, v. 17, n. 2, jul./dez. 1999.

EUROMONITOR INTENATIONAL. Vendas no mercado interno brasileiro de café (R\$). 2015. Disponível em: https://www.abic.com.br/wp-content/ uploads/2020/01/Euromonitor_Coffe-Market-Trends-inBrazil_-Encafe.pdf. Acesso em: 14 dez. 2016. 
EUROMONITOR INTERNACIONAL. Tendências do mercado de café. Abril de 2016. 2016. Disponível em: http:// www.consorciopesquisacafe.com.br/index.php/consorcio/ separador2/observatorio-do-cafe. Acesso em: 14 dez. 2016.

\section{EUROMONITOR INTERNATIONAL. Tendências} mercado de café. Euromonitor, nov. 2017. Disponível em: http:/consorciopesquisacafe.com.br/arquivos/consorcio/ consumo/tendencias_do_mercado_cafe_2017.pdf. Acesso em: 01 de jul. 2020.

FIESP; ITAL. Brasil Food Trends 2020. 2010. Disponível em: http://www.brasilfoodtrends.com.br/Brasil_Food_ Trends/index.html. Acesso em: 13 mar. 2017.

FISCHLER, C. El (h)omnívoro: El gusto, lacocina y el cuerpo. Barcelona: Anagrama, 1995.

FONSECA, A. B. et al. Modernidade alimentar e consumo de alimentos: contribuições sócioantropológicas para a pesquisa em nutrição. Ciência \& Saúde Coletiva, v. 16, p. 3853-3862, 2011.

FRANÇA, F. C. O. et al. Mudanças dos hábitos alimentares provocados pela industrialização e o impacto sobre a saúde do brasileiro. In: SEMINÁRIO ALIMENTAÇÃO E CULTURA NA BAHIA, 1, 2012, Feira de Santana. Anais... Feira de Santana: UEFS, 2012, p. 13-15.

GERDING, T. K.; RIJK, M. A. H.; JETEN, J. Trends in food packing: arising oppurtunities and shifting demands. Packaging Technology and Science, Neew York, v. 9, n. 3, p. 153-65, 1996.

GUERRA, I. C. Pesquisa qualitativa e análise de conteúdo: sentidos e formas de uso. Estoril, Principia Editora, 2006.

GUTMAN, J. A means-end chain model based on consumer categorization processes. The Journal of Marketing, New York, v. 46, n. 2, p. 60-72, 1982.

GUTMAN, J. Exploring the nature of linkages between consequences and values. Journal of Business Research, New York, v. 22, n. 2, p. 143-148, 1991.

JEUNON, E. E. Valores e orientação de consumo: proposta e validação de um modelo integrativo. In: ENCONTRO DA ANPAD, XXIX, 2005, Brasília. Anais... Curitiba: ANPAD, 2005.
MARTINS, M. Atitude relativamente à máquina de café em cápsula: estudo sobre razões de compra. 2013. 199 f. Dissertação (Mestrado em Publicidade e Marketing) Escola Superior de Comunicação Social, Lisboa, 2013.

OLIVEIRA, T. M. V.; IKEDA, A. Usos e limitações do método laddering. Revista de Administração Mackenzie, São Paulo, v. 5, n. 1, p. 198-222, 2008.

REYNOLDS, T. J.; GUTMAN, J. Laddering theory, method, analysis, and interpretation. Journal of Advertising Research, Cambridge, v. 28, n. 1, p. 11-31, 1988.

RICHERS, R. O enigmático mas indispensável consumidor: teoria e prática. Revista de Administração, São Paulo, v. 19, n. 3, p. 46-56, 1984.

ROKEACH, M. The role of values in public opinion research. Public Opinion Quarterly, Oxford, v. 32, n. 4, p. $547-559,1968$.

ROKEACH, M. Crenças, atitudes e valores. Rio de Janeiro: Interciência, 1981.

SCHWARTZ, S. H. Universals in the content and structure of values: theory and empirical tests in 20 countries. Advances in Experimental Social Psychology, New York, v. 25, n. 1, p. 1-65, 1992.

TEIXEIRA, A. P. P. Do coador de pano à cápsula: as mudanças nas práticas de consumo de café no Brasil nos últimos 50 anos. 2014. 128f. Dissertação (Mestrado em Administração) - Universidade do Vale do Rio dos Sinos, São Leopoldo, 2014.

VIECELLI, P. C. Consumo alimentar contemporâneo: um estudo dos hábitos e dos perfis de consumidoras (es) de alimento no município de Pato Branco - PR. 2019. 202 f. Dissertação (Mestrado) - Universidade Tecnológica Federal do Paraná, Programa de Pós-Graduação em Desenvolvimento Regional, Pato Branco, PR, 2019.

VILAS BOAS, L. H. Comportamento do consumidor de produtos orgânicos: uma análise na perspectiva da teoria da cadeia de meios e fins. 2005. 222f. Tese (Doutorado em Administração) - Universidade Federal de Lavras, Lavras, 2005.

WALKER, B.A.J.; OLSON C. Means-end chains: connecting products with self. Journal of Business Research, New York, v. 22, n. 2, p. 111-118, 1991. 
WUERGES, K. L.; SANTOS, A. C. F.; MORI, A. L. brasileiras. In: SIMPÓSIO DE PESQUISA DOS B.; BENASSI, M. T. Caveol e cafestol em bebidas CAFÉS DO BRASIL, IX, 2015, Curitiba. Anais... de café espresso preparadas com cápsulas comerciais Curitiba, 2015.

Organizações Rurais \& Agroindustriais, Lavras, v. 21, n. 1-3, p. 94-104, 2019 